\section{Military expenditure and economic growth: A survey}

\section{J. Paul Dunne and Nan Tian}

$\mathrm{U}$ ntil recently, a long-standing, impressively large, and growing literature appeared to have failed to result in a scholarly consensus on the effects of military expenditure on economic growth. But the availability of 20 more years of data since the end of the cold war has helped researchers to make progress in identifying any relation of military expenditure with economic factors. The literature is complex and difficult to summarize, with studies differing in their theoretical approach, in the empirical methods used, in the coverage of countries and time periods employed, and in their quality and statistical significance. This article extends and updates an earlier survey by Dunne and Uye, ${ }^{1}$ now covering almost 170 studies. It finds that more recent studies provide increasingly stronger evidence of a negative effect of military expenditure on growth. The following sections discuss the general nexus between military expenditure and economic growth, reviews general theoretical issues and the empirical literature, and evaluates the effect of adding the more recent studies to the older ones. The final section presents some conclusions.

\section{Military expenditure and economic growth}

Military expenditure is an important issue for the international economy. It has influence beyond the resources it takes up, especially when it facilitates conflict. Of course, countries need some level of security to deal with internal and external threats, but any resource use carries an opportunity cost in that it prevents money and other resources from being alternatively employed for purposes that might directly improve the pace of development. This is particularly important for developing countries as in the post-cold war world most wars have taken place there, and this is unlikely to change any time soon.

When governments undertake military expenditure, they provide wage income and cover other expenses for the armed forces and procure arms for them. Unfortunately, the only reliable data is on military expenditure per se, not on any of its components, and in reviewing the literature one can do no more than simply recognize that arms transfers are an important part of military expenditure. ${ }^{2}$ In developing countries, it is likely that the arms will be imported, particularly advanced weapon systems, and will drain precious reserves of foreign exchange. This suggests that the opportunity cost of military expenditure is likely to be higher than the expenditure itself.

The end of the cold war brought considerable reductions in military expenditure, although not consistently across all of the world's regions. However, as SIPRI's
Yearbooks show, in recent years the declining trend has bottomed out and military expenditure is rising again. While there have been armed conflicts, the major pressure to increase military expenditure seems not to result from any obvious strategic need but from internal pressures by vested interests. $^{3}$

General trends do of course hide more complex patterns. For example, some states have increased military expenditure because of

local insecurity or due to encouragement from arms- producing companies pushing for arms exports. There has also been continued use of economic arguments to justify security expenditures, or to argue against reductions. Within developing countries, especially, much heterogeneity exists regarding their stage of development, the nature of development, the state of their neighbors, their military burden, whether or not they have an arms industry, and the degree of the military's involvement in the governance of the state.

It is worth noting that the military burden-the share of military expenditure in GDP-is low in most states as compared to other GDP components such as health and education. As a result, when there are other and more weighty influences, one may not find a statistically significant effect of military expenditure on the path of national income even if such an effect actually exists. Aside from when countries are actively engaged in conflict, one also might not expect to find statistically significant effects of arms transfers and military expenditure on growth, which makes it all the more interesting that in many cases one does find such effects.

\section{Theoretical issues}

Theory (should) precede empirics, but much of economic theory does not assign an explicit role for military expenditure as a distinctive economic activity. Consequently, one finds a wide range of theoretical specifications in the empirical work. ${ }^{4}$ The neoclassical approach views the state as a rational actor, balancing opportunity costs and security benefits of military expenditure to maximize a national interest. Captured in a social welfare function, arms-related spending is seen as a public good and the economic effects on military expenditure is determined by its opportunity cost, the trade off between it and other spending. Early models of economic growth, which assumed exogenous technical change, have been extended to allow for the effects of changes in education and technology that produce endogenous growth. ${ }^{5}$

In contrast, Keynesian approaches view military expenditure as one aspect of state 
spending to possibly increase output through multiplier effects in the presence of ineffective aggregate demand. In this way increased military expenditure can lead to increased capacity utilization, increased profits, and hence to increased investment and growth. The institutionalist approach combines a Keynesian perspective with a focus on the way in which military expenditure can lead to industrial inefficiencies and to the development of a powerful interest group composed of individuals, firms, and organizations who benefit from defense spending, often referred to as the military industrial complex (MIC). The MIC increases military expenditure through pressure on the state even when there is no threat to justify such expenditure. ${ }^{6}$ Another perspective comes from the Austrian School, questioning military expenditure as a form of statism and collective action leading to war and long-term economic damage.

Writers in the Marxist tradition generally see the role of military expenditure in capitalist development as important, but contradictory. Strands in this tradition differ in their treatment of crisis, the extent to which they view military expenditure as necessary to capitalist development, and the role of the MIC in class struggle. One offshoot, the underconsumptionist approach by Baran and Sweezy, ${ }^{8}$ provides the only theory in which military expenditure is both important in itself and is an integral component of the theoretical analysis. Here, military expenditure is both necessary to maintain capitalism and to prevent stagnation. Monopolistic companies produce goods and control labor costs, leading to inadequate consumption. While military expenditure is wasteful, in the sense of not creating any further output, it does create substitute demand to allow companies to sell goods and realize profits. ${ }^{9}$

The absence of an agreed theory of economic growth means that there is no standard framework into which empirical work on military expenditure can be fitted. Yet, clearly, military expenditure, conflict, and economic capacity (e.g., education, governance, institutions, natural resources) all interact to influence growth. The theoretical work has identified a number of possible channels through which military expenditure might affect an economy, but the relative importance and sign of any such effects and the overall impact on growth can only be ascertained by empirical analysis. An important issue in empirical work concerns the identification problem which results when security threats influence changes in both military expenditure and economic growth so that it is difficult to know whether any relation between the latter two is due to the underlying security threat or whether an additional relation between military expenditure and economic growth exists. All this suggests the need for much skill and caution in interpreting the results of empirical studies. ${ }^{10}$

\section{Empirical findings}

In empirical work, certain choices need to be made. Many of these are conditioned on the theoretical perspective adopted and the data available. The results are likely to be sensitive to the measurement and definition of the variables, to the specification of the estimated equations (especially the other variables included), to the type of data used, and to the estimation method. The resulting variety of studies does make a comparison rather difficult and explains some of the seemingly contradictory findings.

In a now classic correlational study, Emile Benoit started the empirical debate in 1973 by finding a positive association between military expenditure and development in developing countries. ${ }^{11}$ There were two responses to this. One criticized Benoit's approach, arguing that the complexities and specificities of the underlying processes call for detailed, individual country case studies. The second argued that the empirical work was flawed, and this led to a plethora of econometric studies. Some early contributions employed models with both Keynesian and neoclassical features, within simultaneous equation systems. This approach emphasized the interdependence between military expenditure, growth, and other variables, with the majority of the studies tending to confirm the existence of a negative effect of military expenditure on economic growth and development. Varying in their use of data, some dealt with cross-section averages, others with time-series estimates for individual countries, and others were more comprehensive still. ${ }^{12}$ These types of modeling approaches have become rarer and neoclassical and New Keynesian models more dominant. ${ }^{13}$

A studies used neoclassical-type, but single-equation growth models, introducing military expenditure (in forms such as burden, per capita, or absolute value) as the or one of the, independent variables. For example, Peter Frederiksen and Robert Looney re-examined Benoit's data in this manner but divided the sample of countries into resource-constrained and resource-unconstrained. They found that a statistically significant positive relation for military expenditure on growth held for the resourceunconstrained group. ${ }^{14}$ But the relation was negative for the resource-constrained set of states. Other studies tended to find a positive or insignificant effect of military expenditure on growth, although there were studies that did find adverse effects. ${ }^{15}$ To address certain limitations of the earlier studies, some authors then used extended growth models, including a World Bank study which found that high levels of military expenditure detract from growth by reducing the formation of productive capital and distorting resource allocation. ${ }^{16}$ More recently, Rati Ram, using a large panel of countries, found no evidence of crowding out but clear differences across groups of countries. ${ }^{17}$ And in a forthcoming study, Dunne and Tan find a statistically significant negative effect of military spending on growth and found this result to be surprisingly robust when using a range of potentially important variables (such as conflict and foreign aid) to stratify a large panel using post-cold war data. ${ }^{18}$

An important concern with the single-equation approach was how to determine causality. ${ }^{19}$ This led to a number of studies using Granger-causality techniques. A critical review of this work argued that the lack of theoretical underpinnings means it is very difficult to interpret the results of these studies. Also, inherent limitations of the Granger-causality test often lead to unstable estimates over different time periods or countries, suggesting this method is unreliable in testing for causal links. ${ }^{20}$

Some recent contributions deal with the possibility of a nexus between military expenditure and growth by testing for a nonlinear relationship, or different effects at 
different levels of expenditure. Given the complexity of such models, these studies tend to focus on small numbers of states. For example, one study estimates threshold regressions and shows a level-dependent effect of military expenditure on growth, namely, positive effects for low levels of military expenditure but negative ones for high levels. ${ }^{21}$ But another study finds clear negative effects at both high and low levels of military expenditure. ${ }^{22}$

A further concern of researchers was to allow for the opportunity cost of military expenditure, the trade-off between this and other forms of state expenditure. Early studies found weak evidence of military expenditure crowding out spending on education and health in developing countries, and later studies found no such evidence of trade-offs at all. ${ }^{23}$

An alternative to all of these studies was provided by the existence of large-scale country macroeconometric models, multi-country models, and even world models. Although originally developed for other purposes, the effect of using funds spent on the military for alternative purposes can be analyzed. A collection of such studies was assembled by Nils Petter Gleditsch and colleagues. Jointly, they demonstrated the benefits of a post-cold war "peace dividend". ${ }^{24}$ Because of their complexity, relatively few such studies are available for developing countries. This type of analysis does not search for long-run determinants of growth, as conventional models tend to do, but instead focuses on short- to medium-run peace dividend effects by allowing expenditure policy to shift reductions in military expenditure into alternatives such as debt reduction, tax reduction, or alternative (i.e., non-military) spending.

Many developed economies posses some degree of arms production capacity. While developing countries generally sport limited arms production capabilities, they do have some and many have aspirations to become important arms exporters in their own right. For a limited number of states, the trade in weapons is hugely important in providing foreign exchange; for others, it is a drain on foreign exchange reserves and increases their debt burdens. To circumvent this, a burgeoning market in defense offsets has develop. Brauer and Dunne commissioned a range of studies on the role of offsets in development but found not a single case where offsets yielded unambiguous net benefits for a country's economic development. ${ }^{25}$ A number of studies have considered the effect of military spending on debt. For example, Michael Brzoska found that while indebtedness due to arms imports had not increased as much during the 1990s as it did during the 1970s, the increased commercialization of the post-cold war market meant that developing countries now were expected to pay for weaponry rather than receiving them as military “aid”. Nonetheless, for a panel of 11 small industrialized economies, another study found military burden increases the share of external debt in GDP. ${ }^{26}$

Previous surveys of the military expenditure and economic growth literature include Steve Chan (1986), who found a lack of consistency in the results, and Rati Ram (1995), who reviewed 29 studies and concluded that there was little evidence of a positive effect of defense outlays on growth, but that it was also difficult to say the evidence supported a negative effect. J. Paul Dunne (1996), then covering 54 studies, concluded that military expenditure had at best no effect on growth and was likely to have a negative effect; certainly there was no evidence of any positive effect, he argued. Ron Smith (2000) concluded that the literature did not indicate any robust empirical regularity, positive or negative; if anything, however, likelihoods would point toward a small negative effect in the long run, but one that would require considerably more sophistication to find. Joseph Smaldone (2006), in a review of Africa, considered military expenditure to be heterogeneous, elusive, and complex in its effect on the economy, but felt that variations can be explained by intervening variables. For him, effects can be both positive and negative but are usually not pronounced. Negative effects, however, do tend to cut wider and deeper in Africa, and are most severe in countries experiencing legitimacy or security crisis as well as economic and budgetary constraints. In a survey of 103 studies, Dunne and Uye (2010) show that negative effects of military expenditure on growth were reported in 39 and 35 percent of cross-country and case studies, respectively. Only 20 percent found positive effects for both types, while over 40 percent found unclear results.

Table 1 reports the results of an update and extension of Dunne and Uye (2010). It dramatically increases the studies covered from 103 to 168 and now includes nondeveloping economies. "Case study/ies” refers to single country or to small groups of countries, and the "unclear" category means mixed or insignificant results. Almost 44 percent of the cross-country studies, and 31 percent of the case studies, find a negative effect of military expenditure on economic growth, with only around 20 and 25 percent finding positive effects for cross-country and case studies, respectively.

Dunne and Uye (2010) suggested that the increasing use of post-cold war data might be providing more consistency in the results, and this does seem to be the case. When the 168 studies are split into those using predominately cold war-period data and those with more equal or predominately post-cold war data, the results in Table 1 are striking. ${ }^{27}$ Almost 53 percent of post-cold war cross-country studies find military expenditure to exert a negative effect on growth, compared to only 38 percent for the cold war-data period. For case studies, the percentage of studies showing a positive effect also increased, from 21.4 to 30.0 percent.

Table 2 divides the studies into those published between 1973 to 2006 (Panel A) and those published since then (Panel B). Panel A shows results similar to those in Dunne and Uye (2010), with 39 percent of cross-country studies being negative and 40 percent unclear. Case studies show a higher proportion of unclear results, at 46 percent. In either case, only about one-fifth of studies report a positive effect on growth. This is even more strongly apparent for the most recent post-cold war studies: Panel B shows that 55 percent of recent cross-country studies find a negative impact on growth, with only 17 percent finding positive, and 28 percent unclear, results. The proportion of case studies showing a positive relation between military expenditure and growth, however, was higher at 41 percent, with around 18 percent negative and the remaining 41 percent unclear as well. In sum, it appears that while recent cross- 
country studies tend to find negative effects on growth, case studies tend to find positive effects, making them the main driver of the increase in the proportion of studies finding a positive effect. Importantly, however, this cannot been seen as a significant change as there is a selection bias involved. Of the 72 case studies, a remarkable 63 percent are based on just five countries: Greece, India, Pakistan, Turkey, and the United States. ${ }^{28}$ It seems that the case studies are finding positive effects of military expenditure on economic growth only for a specific subset of countries, four of whom form two conflict dyads: Greece and Turkey, and India and Pakistan. $^{29}$

\section{Conclusions}

Military expenditure caries influence beyond the direct resources it takes up, especially when it facilitates conflict. Evaluating its likely economic effects is important, particularly for developing economies, and this has led to a vast and growing literature. It has also led to a variety of results, reflecting the lack of theoretical consensus, issues over data quality and availability, and the development of econometric methods.

Dunne and Uye (2010) provided a comprehensive review of the literature and concluded that there was little or no evidence for a positive effect, and that it is more likely for there to be negative effect, or at best no statistically significant effect at all. In updating their survey, this article adds 65 studies-bringing the total to 168 surveyed studies - and finds that the more recent studies provide increasingly strong evidence of a negative effect of military expenditure on economic growth. It also finds that cross-country studies that use a relatively large amount of post-cold war data are more likely to find negative effects. It is starting to look as though the increased variation in the data after the end of the cold war provides a higher signal-to-noise ratio in the data and thus improves the performance of econometric analyses. When combined with improved panel data techniques, this has allowed researchers to identify what on the whole is a robust negative effect of military expenditure on economic growth. While the case studies do not support this finding, this may well be due to the preponderance of just five countries in the covered studies.

Overall, the findings reported here suggest that reducing military expenditure need not be costly and may contribute to improved economic performance, especially in developing countries. There are outstanding issues in that some countries possess characteristics such that they may not benefit from cuts in military expenditure. Moving to a lower level of militarization does not automatically lead to development, as Brauer observed long ago (1990). Any such change will require good governance, management, and support. Even earlier, Dan Smith and Ron Smith (1980) argued that if there is a relationship between disarmament and development, it may be one that has to be constructed politically, not one that is pre-given by economic forces. It would appear from this survey that these conclusions remain relevant.
Table 1: Comparisons of pre- and post-cold war studies on the effect of military expenditure on economic growth or development

\begin{tabular}{lcccc} 
& Total number & \multicolumn{3}{c}{ Findings (in percent) } \\
& of studies & Positive & Negative & Unclear \\
Type & & & & \\
Cross-country & 96 & 19.8 & 43.8 & 36.4 \\
Case study/ies & 72 & 25.0 & 30.6 & 44.4 \\
Total & 168 & 23.0 & 38.1 & 39.8 \\
Pre-end to cold war & & & & \\
Cross-country & 60 & 20.0 & 38.3 & 41.7 \\
Case study/ies & 42 & 21.4 & 33.3 & 45.2 \\
Total & 102 & 21.6 & 35.3 & 43.1 \\
Post-cold war & & & & \\
Cross-country & 36 & 19.4 & 52.8 & 27.8 \\
Case study/ies & 30 & 30.0 & 26.7 & 43.3 \\
Total & 66 & 24.2 & 40.9 & 34.9
\end{tabular}

Table 2: Comparison of studies published pre- and post-2007

$\begin{array}{lrrrr}\begin{array}{lrll}\text { Panel A: } 1973-2006 \\ \text { Type }\end{array} & & & & \\ \text { Cross-country } & 67 & 20.0 & 38.8 & 40.3 \\ \text { Case study/ies } & 55 & 20.0 & 34.5 & 45.5 \\ \text { Total } & 122 & 20.5 & 36.9 & 42.6 \\ & & & & \\ \text { Panel B: 2007-early 2013 } & & & & \\ \text { Type } & & & & \\ \text { Cross-country } & 29 & 17.2 & 55.2 & 27.6 \\ \text { Case study/ies } & 17 & 41.2 & 17.6 & 41.2 \\ \text { Total } & 46 & 26.1 & 41.3 & 32.6\end{array}$

What does seem increasingly clear is that military expenditure does in general come at an economic cost. The lesson might be that if one wants to have any hope of becoming (militarily) strong, one should invest in one's economy. Once states are economically strong, too much is at stake to risk in war. States may also gain security by becoming important to the world economy, with the major powers protecting them from attack because of the impact any attack would have on the world economy, and thus on them. The best way to security may be through economic growth.

Dunne and Uye stated that "it seems unfortunate that after 25 years of work or so, 
(C) www.epsjournal.org.uk - Vol. 8, No. 1 (2013)

the findings of the review should be so hedged" and that "as we get more post- cold war data we can hopefully better distinguish the trends in the data and so provide more careful analyses of the contemporary world.”30 It would appear from this update of their study that their wishes have been met. The more recent literature is moving toward a commonly accepted, if not yet consensus, view: Military expenditure has a negative effect on economic growth.

\section{Notes}

J. Paul Dunne is at the School of Economics, University of Cape Town, South Africa. The corresponding author, he may be reached at <John.Dunne@uct.ac.za>. Nan Tian is at the School of Economics, University of Cape Town and may be reached at $<$ Nan.Tian@uct.ac.za $>$.

1. Dunne and Uye (2010).

2. It is important to note that there still are considerable conceptual issues and measurement errors as regards military expenditure. Legacy costs for example are not usually included.

3. Dunne, Perlo-Freeman, and Smith (2008).

4. Dunne and Coulomb (2008).

5. See d'Agostino, Dunne, and Pieroni (2012).

6. See Dunne and Sköns (2010).

7. Westley, Anderson, and Kjar (2011).

8. Baran and Sweezy (1966).

9. See Dunne and Uye (2010).

10. Smith (2000). If the economic determinants of growth are constant, but there are variations in the security threat, a negative relationship between military expenditure and output will be observed. In contrast, if the threat is constant and the economic variables are changing, a positive relationship will be observed. This can be used to explain some country experiences with different combinations of growth and military expenditure.
11. Benoit (1973). The book was mostly neglected, and the debate did not commence until Benoit published a summary in journal form in 1978.

12. Dunne (1996).

13. Dunne and Uye (2010).

14. Frederiksen and Looney (1983).

15. See Dunne (1996).

16. Knight,Loayza, and Villanueva (1996).

17. Ram (2003).

18. Dunne and Tan (2013).

19. Joerding (1986).

20. Dunne and Smith (2010).

21. Cuaresma and Reitschuler (2004).

22. Pieroni (2009).

23. Dunne and Uye (2010).

24. Gleditsch, et al. (1996)

25. Brauer and Dunne (2004).

26. Brzoska (2006); Dunne, Perlo-Freeman, and Soydan (2004).

27. Using 1990 as the cold war reference period, any study that used less than 10 years of data post-1990, or post-cold war data that amounted to less than one-third of the overall sample, was classified as "pre-end to cold war", and vice-versa.

28. The number of studies per country are: USA (19 studies), Greece (12), Pakistan and India (7 in total), Turkey (7), plus 27 other cases. 
29. The isolate the effect of the preponderance of just five countries in the case studies, one would have "average" the findings for each of them and set this against an average for the remaining case studies. This has not yet been done.

30. Dunne and Uye (2010, p. 303).

References

D’Agostini, G., J.P. Dunne, and L. Pieroni. 2012. “Corruption, Military Spending and Growth.” Defence and Peace Economics. Vol. 23, No. 2, pp. 591-604.

Baran, P. and P. Sweezy. 1966. Monopoly Capital. Monthly Review Press: London.

Benoit, E. 1973. Defense and Growth in Developing Countries. Boston, MA: Heath, Lexington Books.

Benoit, E. 1978. "Growth and Defense in Developing Countries." Economic Development and Cultural Change. Vol. 26, No. 2, pp. 271-280.

Brauer, J. 1990. "Reviving or Revamping the 'Disarmament-for-Development' Thesis?” Bulletin of Peace Proposals. Vol. 21, No. 3, pp. 307-319.

Brauer, J. 2002. "The Arms Industry in Developing Nations: History and Post-Cold War Assessment,” pp. 101-127 in J. Brauer and J.P. Dunne, eds. Arming the South: The Economics of Military Expenditures, Arms Production and Trade in Developing Countries. London: Palgrave.

Brauer, J. and J.P. Dunne, eds. 2002. Arming the South: The Economics of Military Expenditures, Arms Production and Trade in Developing Countries. London: Palgrave.

Brauer, J. and J.P. Dunne, eds. 2004. Arms Trade and Economic Development: Theory, Policy, and Cases in Arms Trade Offsets. Routledge: London.

Brauer, J. 2002. "Survey and Review of the Defense Economics Literature on Greece and Turkey: What Have We Learned?” Defence and Peace Economics. Vol. 13, No. 2, pp. 85-107.

Brzoska, M. 2006. “Analysis of Recommendations for Covering Security Expenditures Within and Outside of Official Development Assistance.” Bonn, Germany: Bonn International Centre for Conversion, Research Paper No. 53.

Chan, S. 1987. "Military Expenditures and Economic Performance," in World Military Expenditures and Arms Transfers. Washington, D.C.: U.S. Arms Control and Disarmament Agency.

Collier, P. 2007. The Bottom Billion. Oxford, UK: Oxford University Press.

Cuaresma, J.C. and G. Reitschuler. 2004. "A Non-linear Defence Growth Nexus? Evidence from the U.S. Economy.” Defence and Peace Economics. Vol. 15, No. 1, pp. 71-82.

Dunne, J.P. 1996. "Economic Effects of Military Expenditure in Developing Countries: A Survey,” chapter 23 in N.P. Gleditsch, ed. The Peace Dividend. Amsterdam: Elsevier.
Dunne, J.P., S. Perlo-Freeman, and A. Soydan. 2004. "Military Expenditure and Debt in Small Industrialized Economies: A Panel Analysis.” Defence and Peace Economics. Vol. 15, No. 2, pp. 125-132.

Dunne, J.P. and F. Coloumb. 2008. "Peace, War and International Security: Economic Theories,” pp. 13-36 in J. Fontanel and M. Chatterji, eds. War, Peace, and Security. Bingley, UK: Emerald.

Dunne, J.P., S. Perlo-Freeman, and R.P. Smith. 2008. "The Demand for Military Spending: Hostility versus Capability.” Defence and Peace Economics. Vol. 19, No. 2, pp 293-302.

Dunne, J.P. and E. Sköns. 2010. “Military Industrial Complex,” pp. 281-292 in in A Tan, ed. The Global Arms Trade: A Handbook. London: Routledge London.

Dunne, J.P and R.P. Smith. 2010. "Military Expenditure and Granger Causality: A Critical Review.” Defence and Peace Economics. Vol. 21, No. 5-6, pp 427-441.

Dunne, J.P. and M. Uye. 2010. “Military Spending and Development,” pp. 293-305 in A. Tan, ed. The Global Arms Trade: A Handbook. London: Routledge.

Dunne, J.P. and N. Tian. 2013 (forthcoming).”Military Expenditure and Economic Growth: A Panel Analysis, 1988-2010.” Defence and Peace Economics.

Frederiksen, P. and R.E. Looney. 1983. "Defense Expenditures and Economic Growth in Developing Countries.” Armed Forces and Society. Vol. 9, No. 4, pp. 633-645. Gleditsch, N.P,. et al. eds. 1996. The Peace Dividend. Amsterdam: Elsevier.

Gleditsch, N.P., A. Cappelen, and O. Bjerkholt. 1994. The Wages of Peace: Disarmament in a Small Industrialized Economy. Oslo: PRIO and Thousand Oaks, CA: Sage.

Joerding, W. 1986. "Economic Growth and Defense Spending; Granger Causality.” Journal of Development Economics. Vol. 21, pp. 35-40.

Knight, M., N. Loayza, and D. Villanueva. 1996. "The Peace Dividend: Military Spending Cuts and Economic Growth.” Washington, D.C.: World Bank Policy Research Working Paper No 1577.

Luca P. 2009. "Military Expenditure And Economic Growth.” Defence and Peace Economics. Vol. 20, No. 4, pp. 327-339.

Ram, R. 1995. "Defense Expenditure and Economic Growth,” pp. 251-274 in K. Hartley and T. Sandler, eds. Handbook of Defense Economics. Volume 1. Amsterdam: Elsevier.

[SIPRI] Stockholm International Peace Research Institute. Various years. Yearbook: World Armament and Disarmament. Oxford: Oxford University Press.

Smaldone, J.P. 2006. “African Military Spending: Defence versus Development?” African Security Review. Vol 15, No. 4, pp. 18-32.

Smith, D. and R.P. Smith. 1980. "Military Expenditure, Resources and Development.” University of London, Birkbeck College. Discussion Paper, No. 87 (November).

Smith, R.P. 2000. "Defence Expenditure and Economic Growth,” pp. 15-24 in N.P Gleditsch, G. Lindgren, N. Mouhleb, S. Smit, and I. de Soysa, eds. Making Peace 
The Economics of Peace and Security Journal, ISSN 1749-852X

(C) www.epsjournal.org.uk - Vol. 8, No. 1 (2013)

Pay: A Bibliography on Disarmament and Conversion. Claremont, CA: Regina Books.

Westley, C., W.L. Anderson, and S.A. Kjar. 2011. "War and the Austrian School: Ludwig von Mises and Friedrich von Hayek." The Economics of Peace and Security Journal. Vol. 6, No. 1, pp. 28-33. 